\title{
SEM Analysis of the Interfacial Transition Zone between Cement-Glass Powder Paste and Aggregate of Mortar under Microwave Curing
}

\author{
Yaning Kong ${ }^{1}$, Peiming Wang ${ }^{1, *}$, Shuhua Liu ${ }^{2}$, Guorong Zhao ${ }^{1}$ and Yu Peng ${ }^{3}$ \\ 1 School of Materials Science and Engineering, Tongji University, Shanghai 201804, China; \\ kongyaning1224@126.com (Y.K.); zhaoguorong1986@163.com (G.Z.) \\ 2 State Key Laboratory of Water Resources and Hydropower Engineering Science, Wuhan University, \\ Wuhan 430072, China; shliu@whu.edu.cn \\ 3 College of Civil Engineering and Architecture, Zhejiang University, Hangzhou 310000, China; \\ pengyucs@gmail.com \\ * Correspondence: prof_pmwang@126.com; Tel.: +86-21-6958-2140; Fax: +86-21-6958-2012 \\ Academic Editor: Jorge de Brito \\ Received: 17 June 2016; Accepted: 22 August 2016; Published: 27 August 2016
}

\begin{abstract}
In order to investigate the effects of microwave curing on the microstructure of the interfacial transition zone of mortar prepared with a composite binder containing glass powder and to explain the mechanism of microwave curing on the improvement of compressive strength, in this study, the compressive strength of mortar under microwave curing was compared against mortar cured using (a) normal curing at $20 \pm 1{ }^{\circ} \mathrm{C}$ with relative humidity (RH) $>90 \%$; (b) steam curing at $40{ }^{\circ} \mathrm{C}$ for $10 \mathrm{~h}$; and (c) steam curing at $80^{\circ} \mathrm{C}$ for $4 \mathrm{~h}$. The microstructure of the interfacial transition zone of mortar under the four curing regimes was analyzed by Scanning electron microscopy (SEM). The results showed that the improvement of the compressive strength of mortar under microwave curing can be attributed to the amelioration of the microstructure of the interfacial transition zone. The hydration degree of cement is accelerated by the thermal effect of microwave curing and $\mathrm{Na}^{+}$ partially dissolved from the fine glass powder to form more reticular calcium silicate hydrate, which connects the aggregate, calcium hydroxide, and non-hydrated cement and glass powder into a denser integral structure. In addition, a more stable triangular structure of calcium hydroxide contributes to the improvement of compressive strength.
\end{abstract}

Keywords: SEM; microstructure; ITZ; microwave curing; glass powder

\section{Introduction}

Curing period reduction of precast concrete production has many advantages, e.g., reduction of workshop area, capital saving, and productivity improvement. Steam curing, which takes at least $10 \mathrm{~h}$ to finish one curing cycle before demolding, is the most popular method for precast concrete production [1]. But concrete with low heat conductivity is apt to form a thermal gradient under steam curing, leading to temperature cracks formed by heat stress. High-frequency electromagnetic heating, such as microwave curing, is able to reduce such nonuniformity due to its superior penetration depth. In addition, microwave curing exhibits the characteristics of energy saving, rapid stripping for precast concrete [2,3] or concrete repair [4], which is effective in accelerating the hydration of cement [5-8] or improving the pozzolanic reaction of supplementary cementitious materials (SCMs) [9-14]. According to the research of $\mathrm{Wu}$ et al., microwave curing increases the early strength without any detrimental effect at later ages [15]. The specimens under microwave curing decreased the porosity, which is beneficial to the reduction of plastic shrinkage. Leung et al. also showed that early strength at $4.5 \mathrm{~h}$ and later age strength at 7 days of concrete prepared with type III Portland cement under microwave 
curing are very comparable with concrete containing accelerating admixtures as well as commercially available rapid hardening concrete [16]. Recently published work by Makul et al. showed that the strength of specimens under a Cober Electronics industrial microwave generator $(2.45 \mathrm{GHz}, 6.0 \mathrm{~kW})$ increased when compared with that cured under autoclaved and lime saturated conditions, particularly at early ages [17].

Concrete consists of matrix, aggregate and interfacial transition zones (ITZ) [18]. ITZ is considered the weakest part of the concrete, leading to lower compressive strength than aggregate and hardened cement paste [19]. Furthermore, the micro cracks in ITZ contribute to the transformation of cement-based materials under loading from linear response to the nonlinear response [20]. From the mechanical perspective, the level of micro cracks in ITZ is determined by the mismatch degree of strain between aggregate and paste [21]. Under the condition of homogeneous stress, the difference of strain is attributed to the elasticity modulus and the shear modulus of aggregate, matrix, and ITZ and stress concentration. The ITZ bridges the matrix and aggregate. If the ITZ fails to transfer the stress from one phase to another, the compressive strength of concrete is weakened even with the phase having a higher stiffness [22]. In order to understand the mechanism of ITZ formation and the effects of ITZ on the concrete properties, microstructural analysis was performed in detail. It has been identified that enrichment of calcium hydroxide $\left(\mathrm{Ca}(\mathrm{OH})_{2}, \mathrm{CH}\right)$ and relatively high porosity and large capillary pores affect the mechanical properties significantly. The micro cracks are apt to form perpendicular to the c-axis because of the enrichment of $\mathrm{CH}$ around the aggregate and the c-axis orientation paralleling the surface of aggregate [18]. In addition, the large sized $\mathrm{CH}$ weakens the van der Waals force, resulting in the decrease of cementitiousness, which is adverse to the mechanical properties. In addition to the $\mathrm{CH}$, micro cracks and high porosity are easy to form in ITZ, which reduce the mechanical properties further. In order to ameliorate the ITZ, supplementary cementitious materials (SCMs) are commonly used. SCMs can improve the mechanical property and durability and also improve the compactness and reduce the thickness of ITZ [23,24]. In this study, waste glass powder was used as SCM to improve the ITZ. Waste glass consists of mainly amorphous $\mathrm{SiO}_{2}$ (about 70\%). The amorphous $\mathrm{SiO}_{2}$ can be dissolved in the alkali environment and react with calcium hydroxide to form secondary calcium silicate hydrate (C-S-H). In addition, a certain amount of $\mathrm{CaO}, \mathrm{Al}_{2} \mathrm{O}_{3}$ and $\mathrm{Na}_{2} \mathrm{O}$ exists in glass [25,26]. Three reasons contribute to the accelerated hydration of cement at early ages. Firstly, the reaction of glass powder with $\mathrm{Ca}^{2+}$ in the solution; secondly, the catalytic action of $\mathrm{Na}^{+}$dissolved from glass powder; and thirdly, the increase of sites for nucleation and growth of C-S-H by glass powder [27]. The secondary reaction activation of glass powder is mainly controlled by the fineness and the curing temperature. Increase of specific surface area [28] or increase of curing temperature [29] can improve the activation of glass powder. The pozzolanic reactivity of glass powder can improve the microstructure of paste, thereby ameliorating the strength and durability at later ages [30]. In addition, alkali-silica reaction expansion of mortar containing glass powder is negligible. Waste glass powder as a kind of SCM is also beneficial in the reduction of expansions in a mortar undergoing alkali-silica reaction due to the increased dissolution of $\mathrm{Na}^{+}$by the glass waste aggregate [31-33].

In this study, the effects of microwave curing on the microstructure of the interfacial transition zone of mortar and the mechanism of microwave curing on the improvement of compressive strength were investigated. The compressive strength of mortar under microwave curing was compared with that cured using (a) normal curing at $20 \pm 1{ }^{\circ} \mathrm{C}$ with $\mathrm{RH}>90 \%$; (b) steam curing at $40{ }^{\circ} \mathrm{C}$ for $10 \mathrm{~h}$; and (c) steam curing at $80^{\circ} \mathrm{C}$ for $4 \mathrm{~h}$. The microstructure of the interfacial transition zone of mortar under the four curing regimes was analyzed by scanning electron microscopy/energy dispersive spectrometry (SEM-EDS).

\section{Results}

\subsection{Compressive Strength}

The compressive strength of mortar at the age of one day and 28 days is shown in Figures 1 and 2. At the age of one day, under normal curing, the compressive strength of mortar at the replacement 
ratio of $15 \%$ is slightly higher than the controls, which is attributed to the filling and nucleation effect of glass powder as SCM. Under steam curing, although the hydration of glass powder will be accelerated, the hydration of glass powder is much slower than that of the cement. Therefore, the compressive strength decreases with the increase of replacement ratio. The compressive strength of mortar under microwave curing is the highest among the four curing regimes. At the replacement ratio of $15 \%$ and $30 \%$, the advantage of microwave curing is even more significant. This may be caused by a denser structure resulting from the filling effect, the nucleation effect of glass powder, and the plastic shrinkage of mortar by the decrease of water to binder ratio during the curing.

At the age of 28 days, with the replacement ratio of $15 \%$ or $30 \%$, the pozzolanic reaction of glass powder under normal curing and steam curing becomes visible, leading to a compressive strength that is higher than the controls. However, at the replacement ratio of $45 \%$, the compressive strength decreased, which is different than the research by Du et al. [34]. This is caused by the relatively small specific surface area. In this study, the specific surface area of glass powder was $270 \mathrm{~m}^{2} / \mathrm{kg}^{\prime}$ which decreased its pozzolanic activity.

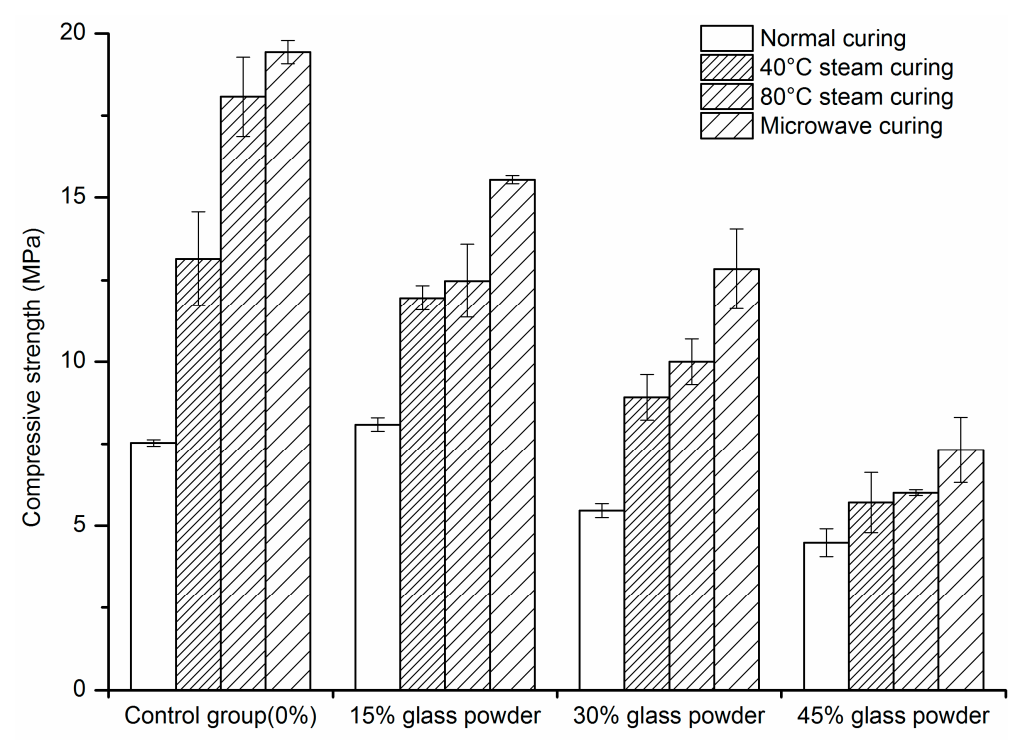

Figure 1. Compressive strength of mortar at one day.

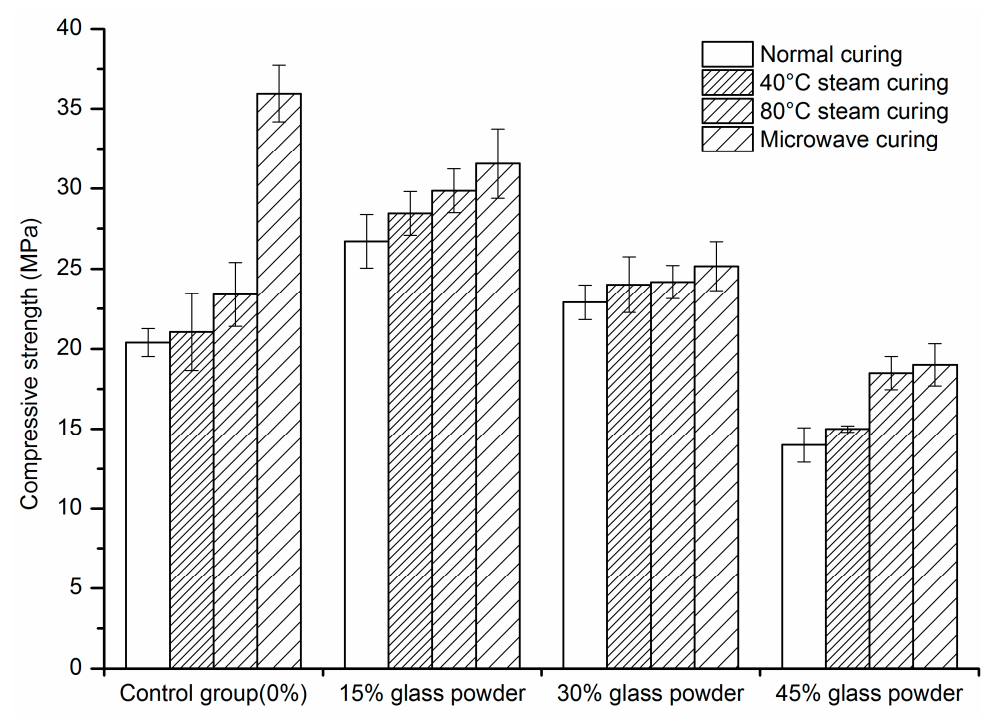

Figure 2. The compressive strength of mortar at 28 days. 


\subsection{SEM Microanalysis}

In order to investigate the effects of microwave curing on the ITZ, the fracture morphology of mortar prepared with composite binder containing 30\% glass powder at the age of one day and 28 days was observed by SEM. The results are shown in Figures 3 and 4 . The element composition of hydration products were also analyzed by EDS, as listed in Table 1.
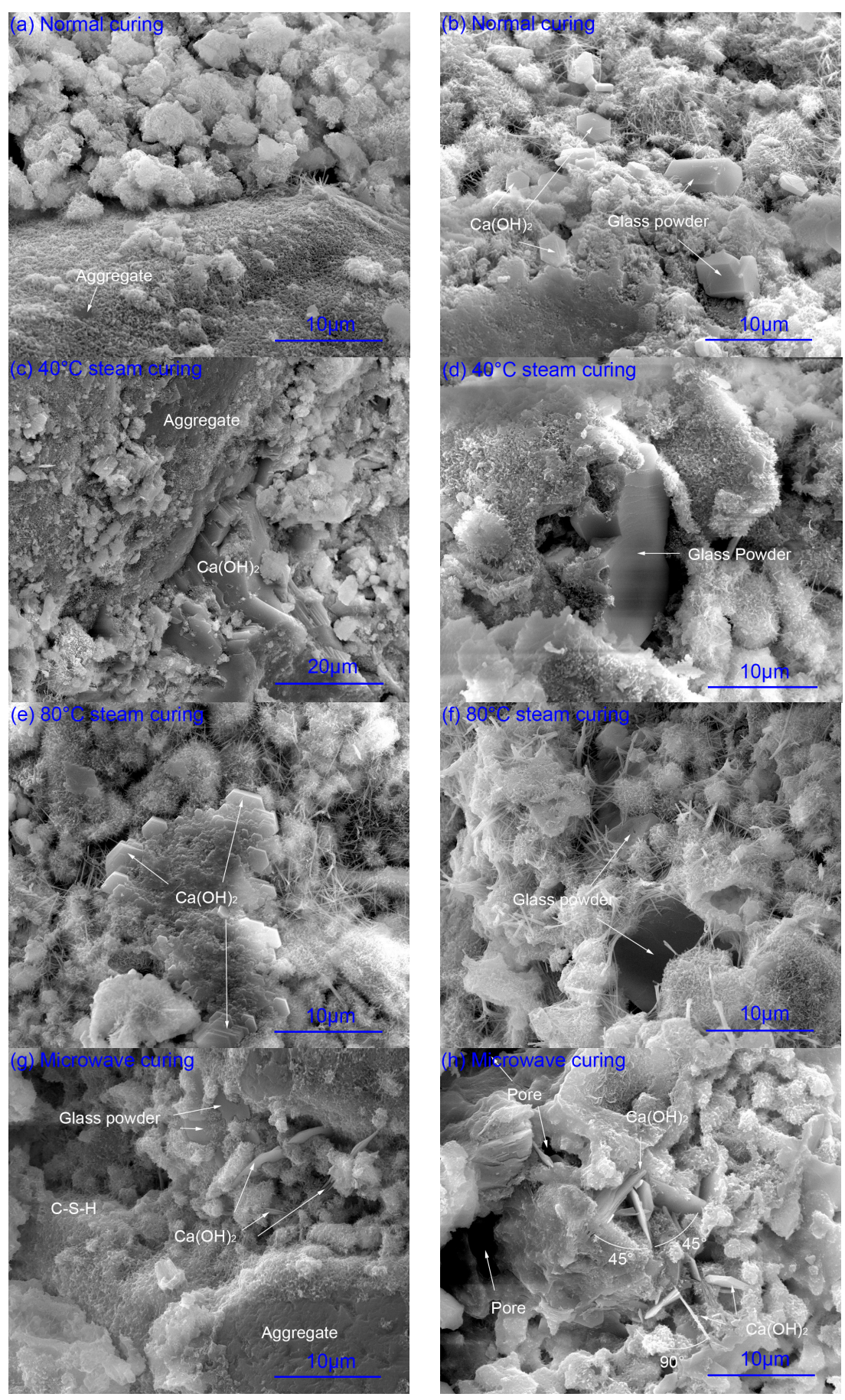

Figure 3. Cont. 

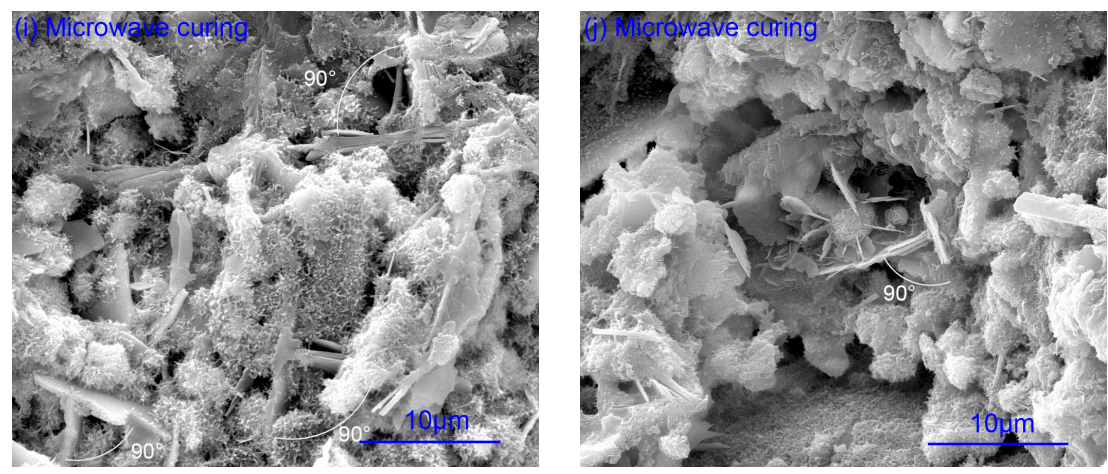

Figure 3. Fracture morphology of mortar prepared with composite binder containing 30 wt \% glass powder at one day. (a,b) normal curing; (c,d) $40{ }^{\circ} \mathrm{C}$ steam curing; (e,f) $80{ }^{\circ} \mathrm{C}$ steam curing; $(g-\mathbf{j})$ microwave curing.
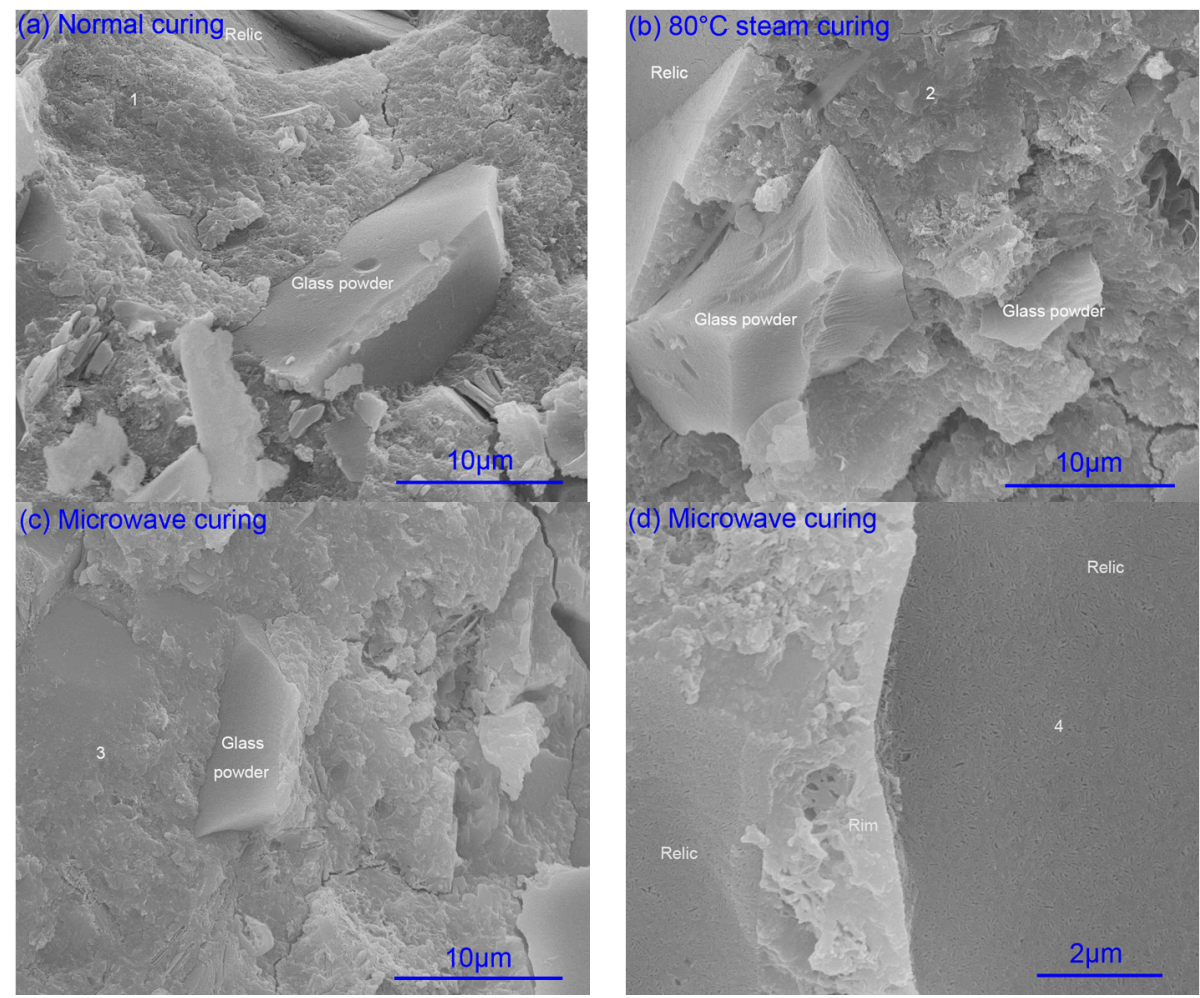

Figure 4. Fracture morphology of mortar at 28 days. (a) normal curing; (b) $80{ }^{\circ} \mathrm{C}$ steam curing; (c,d) microwave curing.

Table 1. Element composition of calcium silicate hydrate.

\begin{tabular}{ccccccccccc}
\hline EDS Spots in Figure 4 & $\mathbf{O}$ & $\mathbf{N a}$ & $\mathbf{M g}$ & $\mathbf{A l}$ & $\mathbf{S i}$ & $\mathbf{S}$ & $\mathbf{K}$ & $\mathbf{C a}$ & $\mathbf{N a} / \mathbf{S i}$ & $\mathbf{C a} /(\mathbf{S i}+\mathbf{N a})$ \\
\hline 1 & 62.75 & 2.29 & 1.67 & 2.76 & 12.87 & 1.62 & 0.99 & 15.05 & 0.18 & 0.99 \\
2 & 59.73 & 2.82 & 0.66 & 1.72 & 13.62 & 1.66 & 0.8 & 19.01 & 0.21 & 1.16 \\
3 & 44.38 & 3.09 & 1.36 & 2.14 & 17.12 & 1.99 & 1.29 & 28.62 & 0.18 & 1.42 \\
4 & 34.05 & 5.07 & 1.49 & 3.26 & 17.22 & 3.54 & 2.1 & 33.27 & 0.29 & 1.49 \\
\hline
\end{tabular}

\subsubsection{Hydration of Glass Powder}

At the age of one day, the surface of glass powder under normal curing (Figure $3 a, b)$ is smooth, showing that the glass powder mainly plays a filling effect. The glass powder fills into the capillary 
pores and is locked mechanically with other phases to contribute to the compressive strength. Large amounts of C-S-H are precipitated on the surface of glass powder under steam curing (Figure $3 \mathrm{~d}, \mathrm{f}$ ) and microwave curing (Figure 3g). Furthermore, the glass powder is wrapped into the dense C-S-H gel. The hydration of glass powder under microwave curing can also be reflected by the $\mathrm{pH}$ in Figure 7 . The reaction of $\mathrm{SiO}_{2}$ in glass powder with calcium hydroxide hydrated by cement forms C-S-H gel and leads to the decrease of the $\mathrm{pH}$ at $6 \mathrm{~h}$. Then, the hydration rate of cement is faster than that of glass powder, leading to an increase of $\mathrm{pH}$ after $6 \mathrm{~h}$ under microwave curing. According to the research of M. Mirzahosseini et al., the dissolution of $\mathrm{Na}^{+}$increases significantly when the $\mathrm{pH}$ is higher than 13.5 with the temperature at $50{ }^{\circ} \mathrm{C}$ [25]. In this study, the content of $\mathrm{Na}_{2} \mathrm{O}$ is $13.2 \%$. It can be seen from the Materials and Methods section that $42.7 \%$ of glass powder is smaller than $25 \mu \mathrm{m}$, which is conducive to the dissolution of $\mathrm{Na}$ [25]. Increase of $\mathrm{Na}^{+}$in the solution can accelerate the hydration of cement $[35,36]$. The dissolved $\mathrm{Na}^{+}$enters into the C-S-H around the glass powder to form alkali-silica reaction (ASR) gel with a high $\mathrm{Na} / \mathrm{Si}$ atomic ratio as shown in Table 1, which is in agreement with the findings reported by Serpa et al. and Redden et al. [26,37].

\subsubsection{Calcium Hydroxide}

The hydration degree of cement is the lowest under normal curing. Small sized $\mathrm{CH}$ with hexagonal-platelet morphology was observed in Figure 3a,b. Lamellar structure of $\mathrm{CH}$ under steam curing was formed (Figure 3c,e). As usual, orientation of $\mathrm{CH}$ around aggregate was observed. The connection of layers is by hydrogen bond, which is very weak. The structure and shape of $\mathrm{CH}$ indicates that $\mathrm{CH}$ rarely contributes to the compressive strength. The weak connection of layers of $\mathrm{CH}$ may be the headstream of micro cracks [38]. However, it can be seen from the Figure $3 \mathrm{~h}-\mathrm{j}$ that a $45^{\circ}$ angle or $90^{\circ}$ angle was formed under microwave curing between the layers of $\mathrm{CH}$. The gap between the layers was filled with the precipitation of C-S-H. The $\mathrm{CH}$ layers and the C-S-H form a more stable triangular structure. The connection of $\mathrm{CH}$ and $\mathrm{C}-\mathrm{S}-\mathrm{H}$ either by mechanical lock or chemical bonding is stronger than the hydrogen bond between the layers of $\mathrm{CH}$. This has a very weak adverse effect of $\mathrm{CH}$ on the compressive strength.

\subsubsection{Pore Structure}

From the Figure $3 \mathrm{a}, \mathrm{b}$, the microstructure of ITZ of mortar under normal curing is very loose. Phases are locked mechanically. This is mainly attributed to the low hydration degree of cement. Steam curing increases the hydration extent, but there are still a lot of non-hydrated cement particles. The capillary pores between the cement particles are still obvious. In addition, some slender ettringite were formed under normal curing and steam curing in the pores (Figure $3 b, d-f$ ).

It can be seen from Figure $3 \mathrm{~h}-\mathrm{j}$, more hydration products were formed under microwave curing. However, a lot of channels are observed. Microwave radiation can heat the mortar to $100{ }^{\circ} \mathrm{C}$ in half an hour or even a few minutes. The gasification of water and expansion of air in the mortar during the plastic stage will increase the capillary pores. The matrix cannot shrink after the microwave curing because of the hardening. In addition, the evaporation of water during microwave curing will also increase the channels during the water transport. From the morphology of the mortar under microwave curing, the diameter of the channels can be classified as capillary pores, which is adverse to the compressive strength and permeability [18]. However, as seen in Figure 3g, the aggregate, glass powder, and cement particles are connected by large amounts of reticular C-S-H into a whole to improve the compressive strength. 


\subsubsection{Element Composition}

$\mathrm{Ca}, \mathrm{Na}$, and the $\mathrm{SiO}_{2}$ network will be dissolved from the glass surface when the $\mathrm{OH}^{-}$attacks the glass to form ASR gel as shown by Equations (1) and (2) [39,40]. In Figure 4d, the gel in the relic of glass powder can be defined as ASR gel according to the element analysis in Table 1.

$$
\begin{gathered}
\mathrm{Ca}^{2+}+\mathrm{Na}^{+}+\left[\mathrm{SiO}(\mathrm{OH})_{3}\right]^{-} \rightarrow \mathrm{C}-\mathrm{N}-\mathrm{S}-\mathrm{H} \\
\mathrm{SiO}_{2}+2 \mathrm{Na}^{+}\left(\mathrm{K}^{+}\right)+2 \mathrm{OH}^{-} \rightarrow \mathrm{Na}_{2}\left(\mathrm{~K}_{2}\right) \mathrm{SiO}_{3} \cdot \mathrm{H}_{2} \mathrm{O}
\end{gathered}
$$

According to Table 1, microwave increases the $\mathrm{Na} / \mathrm{Si}$ atom ratio, leading to the formation of C-S-H containing $\mathrm{Na}(\mathrm{C}-\mathrm{N}-\mathrm{S}-\mathrm{H})$. The adsorption of $\mathrm{Na}^{+}$caused by the secondary reaction of glass powder with $\mathrm{CH}$ makes the $\mathrm{Na}^{+}$unavailable for reaction with silicate [41]. $\mathrm{CaO} /\left(\mathrm{SiO}_{2}+\mathrm{Na}_{2} \mathrm{O}\right)$ determines the swelling property of the ASR gel $[42,43]$. The relative high $\mathrm{Ca}^{2+}$, regardless of form, is beneficial to hindrance of ASR expansion. Therefore, the expansion caused by ASR may be restrained by microwave curing when compared with steam curing and normal curing.

\section{Discussion}

The hydration mechanism of a composite binder under microwave curing is similar to that under steam curing. The hydration of cement can be accelerated by thermal effects. The glass powder mainly plays the role of an inert filler at the early ages, which reduces the porosity of ITZ. At the same time, the partial dissolution of fine glass powder can be accelerated by the increase of temperature. The $\mathrm{SiO}_{2}$ dissolved from glass powder reacts with $\mathrm{CH}$ hydrated by cement to form C-S-H gel. The dissolved $\mathrm{Na}^{+}$ accelerates the hydration of cement to form $\mathrm{C}-\mathrm{S}-\mathrm{H}$ with a high $\mathrm{Na} / \mathrm{Si}$ atomic ratio at the same time.

However, there is a significant difference of microstructure of ITZ between microwave curing and steam curing. In the mortar, except for the aggregate, all the phases contain dielectric materials. The dielectric properties of the materials are different because of relaxation and polarization. Ions will move quickly along with the alternating electromagnetic field. Water molecules are the easiest to influence by microwaves. The fracture of the hydrogen bond can be reflected by the surface tension. According to the results shown in Figure 8, microwaves can break the hydrogen bond to form $\mathrm{OH}^{-}$. $\mathrm{OH}^{-}$will attack the Si-O bond to accelerate the hydration of cement and the dissolution of glass powder. In addition, the movement of ions, especially the $\mathrm{Ca}^{2+}$, with the microwave increases the probability of nucleation, which is good for the precipitation, i.e., $\mathrm{C}-\mathrm{S}-\mathrm{H}$ and $\mathrm{CH}$ formation. However, the hydrogen bond between the layers of $\mathrm{CH}$ is also broken by microwaves. The orientation of $\mathrm{CH}$ is also disturbed, resulting in a $45^{\circ}$ or $90^{\circ}$ angle between the layers of $\mathrm{CH}$. The $\mathrm{CH}$ is then wrapped by C-S-H precipitation to form a more stable triangular structure. The triangular structure can act as fibers to hinder the micro crack propagation by cutting down the spread route. However, the air and water expands or gasifies rapidly during microwave radiation, resulting in the increase of capillary pores, which may be good for frost resistance but is adverse to the compressive strength. In a general, more reticular C-S-H connect the aggregate, glass powder, and non-hydrated cement particles into a denser integral structure. Therefore, although only $45 \mathrm{~min}$ of microwave radiation was performed, the compressive strength of mortar under microwave curing was improved significantly.

\section{Materials and Methods}

The P.I 42.5 cement (China United Cement Corp., Beijing, China) and glass powder from a milled waste glass bottle were used. The waste glass bottle was from wastes disposal station in Shanghai. The chemical composition and particle size distribution of P.I 42.5 cement and the glass powder were tested by X-ray fluorescence spectrometry with SRS 3400 (Bruker AXS, Karlsruhe, Germany) and Laser particle size analyzer LS230 (Beckman Coulter, Indianapolis, IN, USA), respectively. The results are listed in Tables 2 and 3, respectively. In this study, the waste glass powder had higher $\mathrm{SiO}_{2}, \mathrm{CaO}$, and $\mathrm{Na}_{2} \mathrm{O}$, but much lower $\mathrm{Al}_{2} \mathrm{O}_{3}$ contents. According to the Standard Specification for Coal Fly Ash and Raw or Calcined Natural Pozzolan for Use in Concrete (American Society for Testing and Materials, 
C618) and the chemical composition requirement, the glass powder can be classified as Class $\mathrm{N}$ natural pozzolan if $\mathrm{Na}_{2} \mathrm{O}$ content is not a concern. It has been shown that glass powder with particles smaller than $300 \mu \mathrm{m}$ can effectively mitigate ASR and can even be used as an ASR inhibitor in glass aggregate mortars [44]. D10, D50, and D90 in Table 3 represent the diameters corresponding to 10\%, $50 \%$, and $90 \%$ in the cumulative particle size distribution curve. In this study, the characteristic particle diameter of D90 was $110 \mu \mathrm{m}$, which means $90 \%$ of the glass powder is samller than $110 \mu \mathrm{m}$. This is better for mitigation of the adverse effects caused by ASR. The X-ray powder diffraction (XRD)analysis of glass powder was carried out by using a Rigaku D/max 2550 X-ray diffractometer (Rigaku Corp., Tokyo, Japan) with $\mathrm{Cu} \mathrm{K} \alpha$ radiation generated at $40 \mathrm{kV}$ and $100 \mathrm{~mA}$. The scanning rate was $5 \% \mathrm{~min}$. The result is shown in Figure 5. It can be seen that the glass powder mainly consists of amorphous phase. The morphology of glass powder is shown in Figure 6. Silica sand (Xiamen ISO Standard Sand Co., Ltd., Xiamen, China) was used as fine aggregate. The aggregate grading curve is shown in Figure 7. The mortar prepared with pure cement was considered as control group. The replacement ratio of cement by glass powder was $15 \%, 30 \%$ and $45 \%$ by weight. The water to binder ratio of mortar was 0.45 by weight. The volume percentage of fine aggregate was $65 \%$. In general, the thickness of ITZ was $\sim 20-50 \mu \mathrm{m}$ [45]. According to the calculation method mentioned by Sun et al. [46], the ITZ took a great proportion of the paste or even penetrated the paste. The specimens with the diameter of $4 \mathrm{~cm}$ and the height of $8 \mathrm{~cm}$ were prepared by cylindrical molds processed by Nylon with wall thickness of $4 \mathrm{~mm}$.

Table 2. Chemical composition of P.I 42.5 cement and glass powder (wt \%).

\begin{tabular}{ccccccccccc}
\hline & $\mathrm{SiO}_{2}$ & $\mathrm{Al}_{2} \mathbf{O}_{3}$ & $\mathrm{Fe}_{2} \mathbf{O}_{3}$ & $\mathbf{C a O}$ & $\mathbf{M g O}$ & $\mathrm{SO}_{3}$ & $\mathrm{Na}_{\mathbf{2}} \mathbf{O}$ & $\mathrm{Cl}$ & $\mathbf{f}-\mathrm{CaO}$ & Loss on Ignition \\
\hline Cement & 20.81 & 4.92 & 3.41 & 62.65 & 2.38 & 2.65 & 0.67 & 0.012 & 0.81 & 2.01 \\
Glass powder & 71.8 & 1.6 & 0.39 & 10.7 & 0.43 & 0.46 & 13.2 & 0.11 & - & 0.27 \\
\hline
\end{tabular}

Table 3. Particle size distribution and specific surface area of cement and glass powder.

\begin{tabular}{|c|c|c|c|c|c|c|c|}
\hline & \multicolumn{3}{|c|}{ Cumulative Percentage (\%) } & \multicolumn{3}{|c|}{ Characteristic Particle Diameter $(\mu \mathrm{m})$} & \multirow{2}{*}{$\begin{array}{l}\text { Specific Surface } \\
\text { Area }\left(\mathrm{m}^{2} / \mathrm{kg}\right)\end{array}$} \\
\hline & $<25 \mu \mathrm{m}$ & $<45 \mu \mathrm{m}$ & $<80 \mu \mathrm{m}$ & D10 & D50 & D90 & \\
\hline Cement & 66.3 & 89.6 & 98.4 & 2.92 & 17.18 & 47.94 & 347 \\
\hline Glass powder & 42.7 & 63.1 & 81.1 & 1.75 & 33.01 & 110.98 & 270 \\
\hline
\end{tabular}

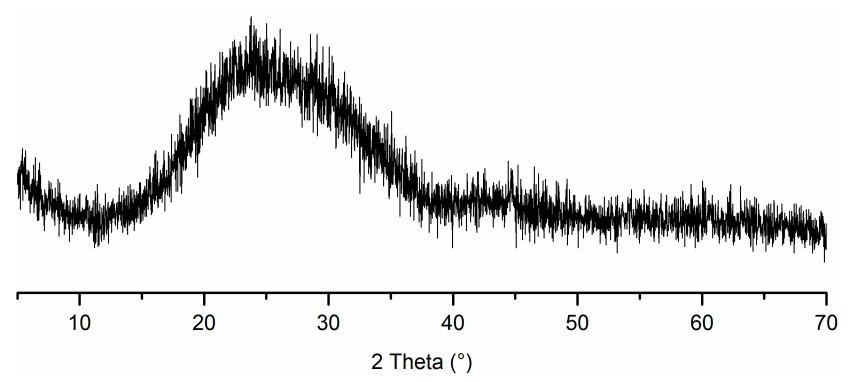

Figure 5. X-ray diffraction pattern of glass powder.

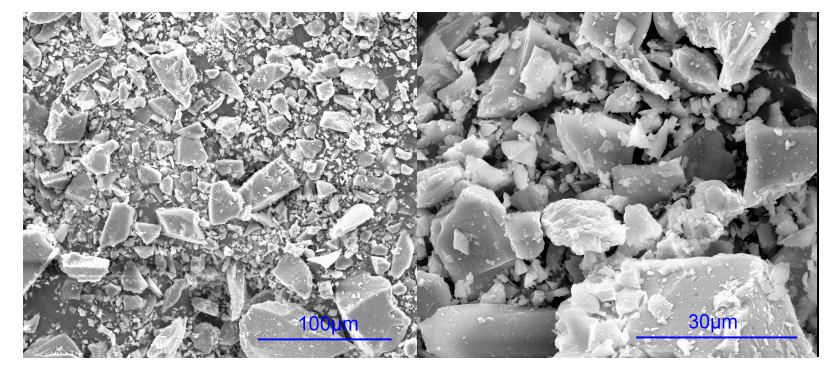

Figure 6. Scanning electron microscope (SEM) pictures of raw glass powder. 


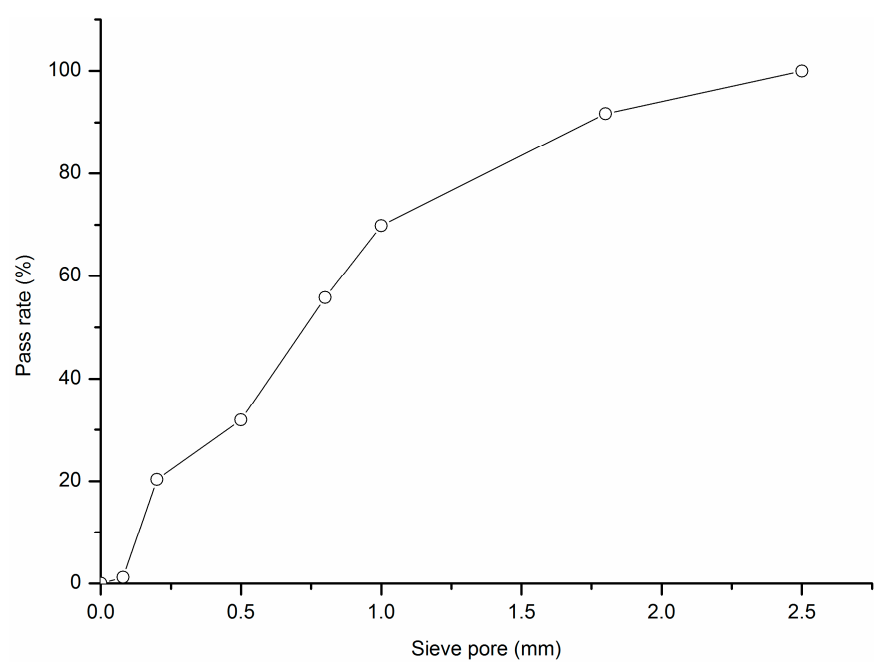

Figure 7. Aggregate grading curve.

Four curing regimes were used in this study. The normal curing was at $20 \pm 2{ }^{\circ} \mathrm{C}$ with relative humidity (RH) $>90 \%$. The steam curing at $40{ }^{\circ} \mathrm{C}$ for $10 \mathrm{~h}$ or $80^{\circ} \mathrm{C}$ for $4 \mathrm{~h}$ had a temperature increase and decrease rate of $15^{\circ} \mathrm{C} / \mathrm{h}$. According to the authors' work [8], the total microwave radiation time of $45 \mathrm{~min}$ was selected. Eight specimens with molds on a turntable at one-time were heated up in a microwave oven (Midea Group. Ltd., Shanghai, China) with an output power of $260 \mathrm{~W}$ and frequency of $2450 \mathrm{MHz}$. The specimens were radiated six times in the microwave oven. The specific microwave curing regime was as follows: The interval time between two radiations was 30 min; the first five radiations were $5 \mathrm{~min}$ and the last radiation was $20 \mathrm{~min}$.

Composite binder containing $30 \%$ glass powder was used for surface tension and $\mathrm{pH}$ test. In this study, $35 \mathrm{~g}$ cement and $15 \mathrm{~g}$ glass powder with $150 \mathrm{~g}$ deionized water $(\mathrm{pH}=7.49$, Surface tension $=73 \mathrm{mN} / \mathrm{m}$ ) were stirred rapidly for $5 \mathrm{~min}$ in a plastic cup. After curing, the upper solution was tested by a HM 200 pH-meter (HM Digital Inc., Seoul, Korea) and a QBZY-1 automatic surface tension tester (Shanghaihengping Co., Shanghai, China). The results are shown in Figure 8.

The compressive strength of mortar was tested by a hydraulic compression testing machine (Wuxiailikang Co., Wuxi, China) with a loading rate of $2.4 \mathrm{kN} / \mathrm{s}$. For later use in SEM analysis, the cores of broken mortar prepared with composite binder containing 30\% glass powder were collected and packed into the ampere bottles filled with absolute ethyl alcohol to terminate hydration. FEI QUANTA 650 and 200 (FEI Co., Hillsboro, OR, USA) were used for the SEM test at one day and 28 days, respectively.

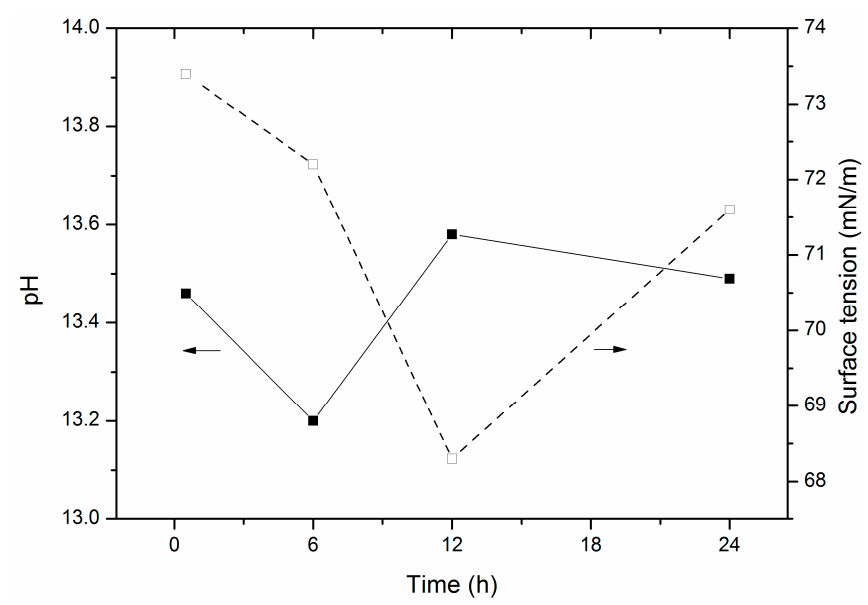

Figure 8. The surface tension and $\mathrm{pH}$ of cement-glass powder solution. 


\section{Conclusions}

The improvement of the compressive strength of mortar prepared with composite binder containing glass powder under microwave curing can be attributed to the amelioration of the microstructure of the interfacial transition zone. The effects of microwave curing on the microstructure of the interfacial transition zone can be concluded as follows: The hydration degree of cement is accelerated by the thermal effect of microwave curing and the partially dissolved $\mathrm{Na}$ from the fine glass powder to form more reticular C-S-H. This connects the aggregate, calcium hydroxide, non-hydrated cement and glass powder into a denser integral structure, and a more stable triangular structure of calcium hydroxide around the aggregate is formed, rather than a lamellar structure, which contributes to the compressive strength improvement.

Acknowledgments: This work was supported by the Twelfth Five-year National Science-technology Support Plan (2012BA20B02), the Fifth Grant Program of the Administrative Office of Laboratory and Equipment of Tongji University (0002015036) and the National Natural Science Foundation of China (51208391).

Author Contributions: Yaning Kong, Peiming Wang and Shuhua Liu conceived and designed the experiments; Yaning Kong and Guorong Zhao performed the experiments; Yaning Kong and Peiming Wang analyzed the data; Guorong Zhao and Yu Peng contributed analysis tools; Yaning Kong wrote the paper.

Conflicts of Interest: The authors declare no conflict of interest. The founding sponsors had no role in the design of the study, in the collection, analyses, or interpretation of data, in the writing of the manuscript, nor in the decision to publish the results.

\section{References}

1. Verbeck, G.J.; Helmuth, R.H. Structures and Physical Properties of Cement Paste. In Proceedings of the 5th International Symposium on the Chemistry of Cement, Tokyo, Japan, 7-11 October 1968; pp. 1-32.

2. Buttress, A.; Jones, A.; Kingman, S. Microwave processing of cement and concrete materials-towards an industrial reality? Cem. Concr. Res. 2015, 68, 112-123. [CrossRef]

3. Makul, N.; Rattanadecho, P.; Agrawal, D.K. Applications of microwave energy in cement and concrete-A review. Renew. Sustain. Energy Rev. 2014, 37, 715-733. [CrossRef]

4. Mangat, P.; Grigoriadis, K.; Abubakri, S. Microwave curing parameters of in-situ concrete repairs. Constr. Build. Mater. 2016, 112, 856-866. [CrossRef]

5. Leung, C.K.; Pheeraphan, T. Very high early strength of microwave cured concrete. Cem. Concr. Res. 1995, 25, 136-146. [CrossRef]

6. Bella, G.D.; Lai, S.; Pinna, M. Beschleunigte erhärtung von beton durch mikrowellen. Betonw. Fert. Tech. (Bft) 1993, 60, 12 .

7. Bella, G.D.; Lai, S.; Pinna, M. Microwaves for the hyperaccelerated curing of concretes [beschleunigte erhartung von beton durch mikrowellen]. Betonw. Fertig. Tech./Concr. Precast. Plant. Technol. 1994, 60, 87-93.

8. Kong, Y.; Wang, P.; Liu, S.; Gao, Z. Hydration and microstructure of cement-based materials under microwave curing. Constr. Build. Mater. 2016, 114, 831-838. [CrossRef]

9. Oriol, M.; Pera, J. Pozzolanic activity of metakaolin under microwave treatment. Cem. Concr. Res. 1995, 25, 265-270. [CrossRef]

10. Zhao, Z.; Song, W.; Dong, B.; Liu, Y.; Long, Y. Effect of microwave radiation activation coal gangue to portland cement system properties. Mater. Rev. 2011, S1.

11. Makul, N.; Agrawal, D.K. Microwave $\left(2.45 \mathrm{GHz}\right.$ )-assisted rapid sintering of $\mathrm{SiO}_{2}$-rich rice husk ash. Mater. Lett. 2010, 64, 367-370. [CrossRef]

12. $\mathrm{X}, \mathrm{H}$. The Effect of Microwave-Activated Lithium Slag on the Coagulation Performance of Sulphoaluminate Cement Concrete; Nanjing University of Science and Technology: Nanjing, China, 2014.

13. Bai, Y.; Shi, S.; Wang, Y.; Li, H.; Xu, D. Hydration and strength development of high volume fly ash/portland cement blend manufactured with room, thermal and microwave curing methods. In Proceedings of the 33rd Cement and Concrete Science Conference, Portsmouth, UK, 2-3 September 2013.

14. Makul, N.; Agrawal, D.K. Microstructure and mechanical properties of microwave-assisted heating of pozzolan-portland cement paste at a very early stage. Songklanakarin J. Sci. Technol. 2013, 35, 693-703. 
15. Wu, X.; Dong, J.; Tang, M. Microwave curing technique in concrete manufacture. Cem. Concr. Res. 1987, 17, 205-210.

16. Leung, C.K.; Pheeraphan, T. Microwave curing of Portland cement concrete: Experimental results and feasibility for practical applications. Constr. Build. Mater. 1995, 9, 67-73. [CrossRef]

17. Makul, N.; Keangin, P.; Rattanadecho, P.; Chatveera, B.; Agrawal, D.K. Microwave-assisted heating of cementitious materials: Relative dielectric properties, mechanical property, and experimental and numerical heat transfer characteristics. Int. Commun. Heat Mass Transf. 2010, 37, 1096-1105. [CrossRef]

18. Mehta, P.K.; Monteiro, P.J.M. Concrete: Microstructure, Properties, and Materials; McGraw-Hill: London, UK, 2006.

19. Ke, Y.; Ortola, S.; Beaucour, A.; Dumontet, H. Identification of microstructural characteristics in lightweight aggregate concretes by micromechanical modelling including the interfacial transition zone (ITZ). Cem. Concr. Res. 2010, 40, 1590-1600. [CrossRef]

20. Akçaoğlu, T.; Tokyay, M.; Çelik, T. Effect of coarse aggregate size and matrix quality on ITZ and failure behavior of concrete under uniaxial compression. Cem. Concr. Compos. 2004, 26, 633-638. [CrossRef]

21. Prokopski, G.; Langier, B. Effect of water/cement ratio and silica fume addition on the fracture toughness and morphology of fractured surfaces of gravel concretes. Cem. Concr. Res. 2000, 30, 1427-1433. [CrossRef]

22. Larbi, J.A. The Cement Paste-Aggregate Interfacial Zone in Concrete; Technical University of Delft: Delft, The Netherlands, 1991.

23. Van Tuan, N.; Ye, G.; Van Breugel, K.; Copuroglu, O. Hydration and microstructure of ultra high performance concrete incorporating rice husk ash. Cem. Concr. Res. 2011, 41, 1104-1111. [CrossRef]

24. Menéndez, G.; Bonavetti, V.; Irassar, E. Strength development of ternary blended cement with limestone filler and blast-furnace slag. Cem. Concr. Compos. 2003, 25, 61-67. [CrossRef]

25. Mirzahosseini, M.; Riding, K.A. Effect of combined glass particles on hydration in cementitious systems. J. Mater. Civ. Eng. 2014, 27, 04014190. [CrossRef]

26. Serpa, D.; Silva, A.S.; de Brito, J.; Pontes, J.; Soares, D. Asr of mortars containing glass. Constr. Build. Mater. 2013, 47, 489-495. [CrossRef]

27. Du, H.; Tan, K.H. Waste glass powder as cement replacement in concrete. J. Adv. Concr. Technol. 2014, 12, 468-477. [CrossRef]

28. Schwarz, N.; Neithalath, N. Influence of a fine glass powder on cement hydration: Comparison to fly ash and modeling the degree of hydration. Cem. Concr. Res. 2008, 38, 429-436. [CrossRef]

29. Liu, S.; Xie, G.; Wang, S. Effect of curing temperature on hydration properties of waste glass powder in cement-based materials. J. Therm. Anal. Calorim. 2015, 119, 47-55. [CrossRef]

30. Du, H.; Tan, K.H. Concrete with recycled glass as fine aggregates. ACI Mater. J. 2014, 111, 47-58.

31. Idir, R.; Cyr, M.; Tagnit-Hamou, A. Use of fine glass as ASR inhibitor in glass aggregate mortars. Constr. Build. Mater. 2010, 24, 1309-1312. [CrossRef]

32. Liu, S.; Wang, S.; Tang, W.; Hu, N.; Wei, J. Inhibitory effect of waste glass powder on ASR expansion induced by waste glass aggregate. Materials 2015, 8, 6849-6862. [CrossRef]

33. Du, H.; Tan, K.H. Effect of particle size on alkali-silica reaction in recycled glass mortars. Constr. Build. Mater. 2014, 66, 275-285. [CrossRef]

34. Du, H.; Tan, K.H. Transport properties of concrete with glass powder as supplementary cementitious material. ACI Mater. J. 2015, 112, 429-439. [CrossRef]

35. Jawed, I.; Skalny, J. Alkalies in cement: A review: II. Effects of alkalies on hydration and performance of Portland cement. Cem. Concr. Res. 1978, 8, 37-51. [CrossRef]

36. Ramachandran, V.; Beaudoin, J.; Sarkar, S.; Xu, A. Physico-chemical and microstructural investigations of the effect of $\mathrm{NaOH}$ on the hydration of $3 \mathrm{CaO} \cdot \mathrm{SiO}_{2}$. Cemento 1993, 90, 73-73.

37. Redden, R.; Neithalath, N. Microstructure, strength, and moisture stability of alkali activated glass powder-based binders. Cem. Concr. Compos. 2014, 45, 46-56. [CrossRef]

38. Yuan, R. Cementitious Materials; Wuhan University of Technology Press: Wuhan, China, 1996.

39. Shi, C. Corrosion of glasses and expansion mechanism of concrete containing waste glasses as aggregates. J. Mater. Civ. Eng. 2009, 21, 529-534. [CrossRef]

40. Glasser, L.D.; Kataoka, N. The chemistry of 'alkali-aggregate'reaction. Cem. Concr. Res. 1981, 11, 1-9. [CrossRef] 
41. Shayan, A.; $\mathrm{Xu}, \mathrm{A}$. Performance of glass powder as a pozzolanic material in concrete: A field trial on concrete slabs. Cem. Concr. Res. 2006, 36, 457-468. [CrossRef]

42. Tang, M.-S.; Xu, Z.-Z.; Han, S.-F. Alkali reactivity of glass aggregate. Durab. Build. Mater. 1987, 4, 377-385.

43. Saccani, A.; Bignozzi, M.C. ASR expansion behavior of recycled glass fine aggregates in concrete. Cem. Concr. Res. 2010, 40, 531-536. [CrossRef]

44. Shi, C.; Wu, Y.; Riefler, C.; Wang, H. Characteristics and pozzolanic reactivity of glass powders. Cem. Concr. Res. 2005, 35, 987-993. [CrossRef]

45. Scrivener, K.L.; Crumbie, A.K.; Laugesen, P. The interfacial transition zone (ITZ) between cement paste and aggregate in concrete. Interface Sci. 2004, 12, 411-421. [CrossRef]

46. Sun, G.W.; Sun, W.; Zhang, Y.S.; Liu, Z.Y. Numerical calculation and influencing factors of the volume fraction of interfacial transition zone in concrete. Sci. China 2012, 55, 1515-1522. [CrossRef]

(C) 2016 by the authors; licensee MDPI, Basel, Switzerland. This article is an open access article distributed under the terms and conditions of the Creative Commons Attribution (CC-BY) license (http://creativecommons.org/licenses/by/4.0/). 